\title{
Language And Attitude: A Review And Reflection On Tourism And Hospitality In NTT Province, Indonesia
}

\author{
Santri E. P. Djahimo, Dewi I. N. Bili Bora \\ \{sunthree_dj@yahoo.com,dewi.bilibora@yahoo.co.id\} \\ English Department, Nusa Cendana University
}

\begin{abstract}
This qualitative study basically aims to produce a review or assessment and reflection on language (i.e. English) ability and attitudes shown by local communities in 10 tourist spots in NTT Province. The data has been collected by using both direct observations and interviews. The results show that most of local people aren't really aware of the importance of having positive attitudes towards visitors/tourists. They also have constraints in communicating with the visitors/tourists because they can't speak English well. There have also been other problems listed down in this article as the findings of this study. All these problems can cause discomfort for travelers who come to visit. These language and attitude aspects are still considered as small problems but they have a major impact on the development of tourism in NTT.
\end{abstract}

Keywords: Language, Attitude, Review, Reflection, Tourism, Hospitality

\section{Introduction}

Tourism industry, especially the one relates to sustainable rural tourism has been increasingly promoted in Indonesia because it becomes a part of national strategic plan to be achieved by the Ministry of Tourism (Junaid, 2015). This is the main reason why this article has been written and published to support the act of sustainable rural tourism promotion.

This article is organized as follows. It is started by providing information relates to the overview of the whole study covered in the abstract. It is followed by the introduction which gives the brief ideas about what the study is about and the reasons why it has been conducted. The next section, review of literature, contains of a brief discussion about the concepts of tourism in general contexts, as they lay the foundation for the development of the study about language and attitude of local communities. Issues are then discussed in the section of discussion based on the findings and results of the study. The final section concludes this article including recommendations for future research directions.

Based on the news of World Travel and Tourism Council, the percentage of Travel and Tourism in Indonesia reached $7.8 \%$ in 2018 , twice as much as the global average which was only $3.9 \%$. This means that this kind of business is growing fast in this country and gives quite a number of contributions to the economic growth in Indonesia. Despite this good news about the increasing number of tourism industry, several weaknesses still occur that can lead to the failure of exploiting its full potential. 
Having more than 17.000 islands with so many beautiful spots and interesting things to offer, Indonesia should have become one of the giant countries in terms of tourism industry. Unfortunately, the tourism potential in Indonesia hasn't been optimally developed. There are many wonderful places all around this country still categorized as "hidden paradises". These spots haven't been touched by the government (less-developed tourist areas) and need to be focused on in the tourism development programs. In addition, human resource is also an essential aspect to be well-developed in handling this kind of industry, especially. those who involve directly in the services of tourists, such as the ones from travel agents, restaurants, souvenir shops, hotels, and all other targeting markets.

East Nusa Tenggara Province (NTT) as one of the 34 provinces in Indonesia also has great tourism potential that hasn't been fully developed. Several spots have been quite popular known, like Mandalika and Labuan Bajo in Flores, others haven't even been identified at all. However, the development of both the spots and the human resource of the popular spots haven't been optimally done. This situation leads us to conduct this kind of review and reflection through this study in order to come up with a better change in tourism industry in NTT Province. This simple and practical study is basically aimed at producing a review or assessment as well as a reflection on language (i.e. English) ability and attitudes shown by local communities in the 10 tourist spots in NTT Province. This kind of review is expected to be able to provide information relates to current condition of tourism and hospitality in NTT Province in general, and tourism awareness and knowledge, in this case, language and attitudes of local communities, in particular.

\section{Review of Literature}

Tourism is a dynamic activity that involves many people and makes use of various fields of business. Every country in the world has done a lot of work to develop a sustainable tourism because this field will power economy, help to deliver prosperity and support communities. The importance of this field has been shown by many experts by finding out the most advanced way in developing tourism industry through research (Pearce, 2005; Hall et al, 2004; Baker et al, 1994; Franklin and Chang, 2001; Dwyer at al, 2004). All of these efforts are aimed at developing tourism factor to make it more effective and advanced.

In spite of using the advanced ways and strategies, tourism awareness has to be applied by those who have been involved in this factor, including local people. However, many studies have shown that there is lack of knowledge and awareness of tourism in local communities (Saufi et al., 2014). This becomes one of the major challenges in tourism development (Sirakaya et al., 2002; Timothy, 1999). The awareness and knowledge are included in the aspects of language and attitude which become the key issues of this study. Language and attitudes are two major focus of this study and how these two aspects relate to tourism development program have been discussed by many authors in various tourism references (Hudman \& Jackson, 2003; Andrews, 2007; Kusluvan, 2003; Eric, 2006; Hudson, 2006).

In their writings, all of these authors discuss about how services are important in tourism industry and how to make efforts to improve tourism and hospitality services. Attitude is included in the effort to improve the services. What it means by attitude in this study is the 
positive attitude shown by the locals towards the visitors. Being able to communicate with the visitors, especially, international ones, by using an understandable language, in this case, English as the most commonly spoken language in the world is closely related to the aspect of knowledge.

Looking at what attitude and knowledge mean above leads us to a thought that the level of language and attitude aspects are still considered below average in the tourism industry in Indonesia in general, and in NTT Province, in particular. This is in a line with what has been stated by Bachri, an Indonesian tourism expert, in a tourism seminar in Bandung, West Java on the $9^{\text {th }}$ of November 2018, that tourists' satisfaction is the main point in developing a tourism object. He further says that the sustainability of tourism industry can only happen if the tourists can become 'repeaters' (they will come back for another or even other visit(s)), and the only reason they become 'repeaters' is if they feel satisfy and comfortable with their first visit. The visitors' satisfaction and comfort are closely related to human factor (Bachri, 2018). He then argues that the two weaknesses of our tourism management are dealing with the issues of security and the irregularities in the aspects of amenities and accessibility. Good strategies need to be applied in order to find solutions of these two problems. Security system needs to be improved in tourism sector and facilities as well as services, including the issues of language and attitude of the locals, must be better developed. These all relate to human factor as has been stated by Bachri (2018).

The target of tourism development in Indonesia as proposed by The Ministry of Tourism can be seen in the following table:

\begin{tabular}{|c|c|c|c|c|c|}
\hline & INDICATOR & $\begin{array}{c}\text { EST. } \\
2104 *)\end{array}$ & 2015 & 2016 & 2019 \\
\hline 1 & $\begin{array}{l}\text { International } \\
\text { (Person) }\end{array}$ & 9,3 Millions & $\begin{array}{l}11,2 \\
\text { Millions }\end{array}$ & 13 Millions & $\begin{array}{l}20,0 \\
\text { Millions }\end{array}$ \\
\hline 2 & Domestic Tourist (Visiting) & $\begin{array}{l}251 \\
\text { Millions }\end{array}$ & $\begin{array}{l}259 \\
\text { Millions }\end{array}$ & $\begin{array}{l}263 \\
\text { Millions }\end{array}$ & $\begin{array}{l}275 \\
\text { Millions }\end{array}$ \\
\hline 3 & $\begin{array}{l}\text { Foreign Exchange (Billion } \\
\text { USD) }\end{array}$ & 10,69 & 12,5 & 14,13 & 20 \\
\hline
\end{tabular}

Source: Book I of RPJMN 2015-2019

*) The data has been processed by the Ministry of Tourism

The table indicates that much work has to be done in order to achieve the targeted numbers set up by the Tourism Ministry in the year 2019. Therefore, this piece of writing is expected to be used as a very simple form of a reference to start developing the tourism industry to be better.

\section{Methods}

Direct observation and interviews have been used as the instruments to collect the data. The observations have been done in 10 tourism spots in East Nusa Tenggara Province. Besides, both domestic and international tourists in those 10 spots have been interviewed to get their opinions and ideas about the spots they are visiting. The questions particularly relate to the 
visitors' impressions about the condition of the spots, the attitudes of the locals, the language (i.e. English) skill of the locals and whether or not they are comfortable being in those places.

The 10 tourism spots are:

1. Waimarang Waterfall; a kind of hidden oasis in the middle of a forest which is located in East Sumba Regency.

2. Nemberala Beach; a beautiful and perfect beach in Rote Ndao where people can do water activities, like surfing.

3. Kelimutu Lake; the three "boiling lakes" on the mountain with different colors which is located in Ende.

4. Lasiana Beach; a beautiful beach with white sands and calm waves in Kupang.

5. Tuamese Hill in Kefamenanu, TTU; a tourist spot on the hill where people can witness an awesome and stunning view.

6. Ena Bhara Beach; a beautiful and quiet beach in Bajawa.

7. Takpala; a traditional village called "hidden paradise of Eastern Indonesia" located in Alor Regency.

8. Kelabba Maja; beautiful and sacred painted hills in Sabu Raijua.

9. Boti Tribe; a tribe in TTS Regency which is located in a remote geographical location in the middle of the mountains that still strictly follow the traditions of their ancestors.

10. Padar; a small island in West Manggarai Regency located between the islands of Komodo and Rinca.

Those spots have been randomly chosen by drawing the lottery in order to keep the data reliable.

The answers to the questions of the interview have been qualitatively analysed and the explanation will be provided in a more detailed description based on the respondents' answers in the discussion part.

\section{Discussion}

In this discussion part, the data from all the 10 spots have been presented and analyzed based on the findings of this study. The results of the findings have revealed several things considered as the weaknesses of the 10 tourism spots in NTT Province. The weaknesses are going to be elaborated below with a further discussion supported by the data collected during the field research.

The first weakness is dealing with the attitude of the local communities. Most of local people aren't really aware of the importance of having positive attitudes towards visitors/tourists. This can be shown by the result of the observations that most locals in the 10 spots don't really care about how to show positive attitudes in welcoming tourists to their places. Some of them are even hard to greet the visitors and smile at them. These findings are strengthened by the results of the interviews as can be seen below:

Interviewer

Domestic Tourist 1

Domestic Tourist 2
What do you think about the local people here?

Now many people are nice. Some even don't know how to treat us well. All they want is to make us buy whatever they sell.

: Good.. They are good.. but few of them don't even smile at me 


\begin{abstract}
International Tourist 1 : Well, few of them are friendly.. but not all.. All I want is to relax and enjoy my time here, but some keep on coming and asking so many things which is annoying.

International Tourist 2 : The tourist guide is okay, but several locals tend to be rude, especially when we don't want to buy their things.
\end{abstract}

It can be seen from the findings that these locals still have problems with the issues of human factor as has been previously stated by Bachri (2018). They can't show their positive attitudes towards the visitors because there is a low level of tourism awareness among the community members. It is assumed that this has been caused by the lack of trainings relate to this matter.

Local tourism awareness and knowledge are essential factors in developing tourism in Indonesia, particularly, rural tourism. Indonesian government has to really pay attention to this aspect because this is one of the ways to eliminate poverty and spread economic benefits across the nation. There should be (a) program(s) to train local communities to increase their tourism awareness and knowledge. This is one way to make tourists become "repeaters" because they feel comfortable during their first visit and want to come back for the next $\operatorname{visit}(\mathrm{s})$.

Another weakness relates to knowledge of language, in this case, English. The local communities have constraints in communicating with international visitors/tourists because they can't speak English well. When these people are interested in interacting with the locals, they have to use tour guides which can create another problem for some of them as quoted in the interview below:

\begin{tabular}{|c|c|}
\hline Interviewer & : Do you interact with the locals during your visit? \\
\hline International Tourist 4 & $\begin{array}{l}\text { : None of them can speak English so it's hard for me to } \\
\text { communicate. }\end{array}$ \\
\hline International Tourist 5 & $\begin{array}{l}\text { I used to be helped by a tourist guide in interpreting things } \\
\text { when I wanted to buy souvenirs and all.. but once I found out } \\
\text { that he cheated on me with the price... he marked up all the } \\
\text { prices.. I stopped using his services. }\end{array}$ \\
\hline
\end{tabular}

Using the services of tourist guides is good as long as the guides have positive attitudes in handling his guests. Once the visitors get bad impressions about their services, they will no longer want to use the guides and the worse thing is they won't want to come back for another visit. Local communities with adequate or even good knowledge about English can communicate well with visitors. Having good communication and interaction can create positive atmosphere and enjoyment during tourists' visits and this can be one of the factors to make them comfortable.

The role of the government is essential in developing the knowledge of local communities. As it has been previously mentioned, a particular training is important to develop the locals' awareness. In addition, a kind of English training is also urgently needed to improve their knowledge of communication. 
Categorizing as less-developed tourist areas, these 10 spots have many other problems (other than the issues of language and attitude) to share to become the main concern for not only government but also all of us, which can be listed below:

1. These 10 spots actually have high potential to become successful tourism destinations. However, Nemberala Beach in Rote Ndao is the only popular and widely known spot because other destinations haven't been optimally promoted. Many kinds of promotional activities have to be done for this purpose. Social media network has been used for quite a long time to bring revolution in tourism industry throughout the world, and this can be one of the best options.

2. No such issue like competitiveness of tourism destinations that will directly influence the tourism-related businesses, such as, hotels, restaurants, and souvenir shops in the destinations, to a certain extent. This happens because these 10 destinations still cannot compete with other well-known tourist spots in Indonesia like beaches of Bali, Mount Bromo, Lake Toba, Borobudur Temple, etc._ in terms of management, promotions, facilities, access, and human resources.

3. The tourism-related business, in this case, hotels, restaurants, and souvenir shops are rarely or even can't be found at all in (close to) the visiting areas.

4. Accessibility and transportation infrastructure; the road system and infrastructure need to be better developed. Furthermore, public transport network has to be improved and expanded.

5. Not many tourist attractions are available in these spots to be experienced or consumed by visitors.

6. These places lack clean water and toilets; improving tourism market means improving all related aspects, including standardized sanitation. Clean water and toilets have to be provided in every tourism spot. Many tourists who come to visit these spots mostly complain that these spots don't provide (standardized) toilets and clean water.

7. The spots are polluted with rubbish; it's disappointing to know the reality that the beautiful scenery of each spot has the ugly side, for being dirty-polluted with rubbish. This might be caused by the tourists who throw rubbish everywhere they like, but this won't happen if rubbish bins are provided in every corner of the place.

The factors previously mentioned can be the major causes of discomfort for travelers who come to visit. The language and attitude problems added by other problems listed above are still considered as small problems and tend to be ignored but they have a great impact on the development of tourism in NTT.

\section{Conclusions and Recommendations}

There are several conclusions can be drawn from this writing, as follows:

1. This study is a small scale one, which of course has limitations relate to sample size, limited questions in the interviews, and limited aspects to observe. Furthermore, it has no clear indicators to measure the local communities' tourism awareness (attitude) and knowledge (language) but only by looking at the respondents' (i.e tourists) answers. 
2. In spite of the limitations of this study, it can be positively stated based on the results that tourism business can grow well in Indonesia, especially in the Province of East Nusa Tenggara, because this province has many interesting tourist attractions.

3. The Province of NTT actually has many wonderful places categorized as "hidden paradises" (less-developed tourist areas) that need to be touched and focused on in the tourism development programs by the government.

4. It's the responsibility of all parties; both government and communities to take good care of all tourism assets in this province and to start developing this industry to become better.

5. In order to grow a successful tourism business, the governments of all levels in this province have an important role to play in the improvement of all aspects of sustainability of tourism, not only dealing with developing tourist spots but also maintaining positive attitudes of local communities as well as improving their ability in communication using English as an international language.

6. There is a room for a future research that still cannot be touched by this recent study, which is dealing with the perceptions of local communities towards both tourism industries and tourist or visitors who visit their places.

\section{References}

[1] Bachri, Thamrin. B. 2018. Oral Presentation in Seminar Pengembangan Destinasi dan Pemasaran Terpadu Danau Toba. Trans Luxury Hotel, Bandung, West Java.

[2] Baker K. G., Hozier G. C., Rodgers R. D. 1994. Marketing Research Theory and Methodology and the Tourism Industry: A Nontechnical Discussion. Journal of Travel Research, 32 (3): 3-7.

[3] Dwyer L., Forsyth P., Spurr R. 2004. Evaluating Tourism's Economic Effects: New and Old Approaches. Tourism Management, 25 (3): 307-317.

[4] Franklin A., Chang M. 2001. The Trouble with Tourism and Travel Theory. Tourist Studies, 1 (1): 5-22.

[5] Hall C. M., Williams A. M., Lew, A. A. 2004. Tourism: Conceptualizations, Institutions, and Issues. In A. A. Lew, C.M. Hall, A. M. Williams (Eds.): A Companionto Tourism. Blackwell, Oxford.

[6] Hudman, Lloyd, E \& Richard H. Jackson. Geography of Travel \& Tourism. Thomson Delmar Learning.

[7] Hudson, Simon., Graham A, Miller, and Paul Hudson. 2006. The Role of Research in Improving Tourism and Hospitality Services: Measuring Service Quality. In Prideaux, B. et al. (Eds.). 2006. Managing Tourism and Hospitality Services: Theory and International Applications, CAB International.

[8] https://www.wttc.org/about/media-centre/press-releases/press-releases/2019/indonesiantravel-and-tourism-growing-twice-as-fast-as-global-average/

[9] Junaid, I., 2015. Enhancing Community Participation: Alternative Frameworks for Sustainable Tourism in Makassar City, Indonesia. International Journal of Scientific and Research Publications, 5 (4), pp. 1.

[10] Kusluvan, Salih. 2003. Managing Employee Attitudes and Behaviors in the Tourism and Hospitality Industry. Nova Science Publishers, Inc. 
[11] Laws, Eric. 2006. Considerations in Improving Tourism and Hospitality Service System. In Prideaux, B. et al. (Eds.). 2006. Managing Tourism and Hospitality Services: Theory and International Applications, CAB International.

[12] Pearce, Douglas. G. 2005. Advancing Tourism Research: Issues and Responses. In Alejziak, W \& R. Winiarski (Eds.). 2005. Tourism in Scientific Research. KrakÓw RzeszÓw.

[13] Saufi, A., O'Brien, D. and Wilkins, H. 2014. Inhibitors to Host Community Participation in Sustainable Tourism Development in Developing Countries. Journal of SustainableTourism, 22 (5), pp. 801-820.

[14] Sirakaya, E., Teye, V. and Sönmez, S. 2002. Understanding Residents' Support for Tourism Development in the Central Region of Ghana. Journal of Travel Research, 41 (1), pp. 57-67.

[15] Sudhir, Andrews. 2007. Introduction to Tourism and Hospitality Industry. Tata McGraw-Hill Publishing Company Limited.

[16] Timothy, D. J., 1999. Participatory Planning A View of Tourism in Indonesia. Annals of Tourism Research, 26 (2), pp. 371-391. 